\title{
Crop management in a district within the Ebro River Basin using remote sensing techniques to estimate and map irrigation volumes
}

\author{
J. G. Ramos ${ }^{1}$, J. A. Kay ${ }^{2}$, C. R. Cratchley ${ }^{2}$, M. A. Casterad ${ }^{3}$, \\ J. Herrero ${ }^{3}$, R. López ${ }^{3}$, A. Martínez-Cob ${ }^{4}$ \& R. Domínguez ${ }^{1}$ \\ ${ }^{1}$ Engineering Institute, National Autonomous University of Mexico, \\ Mexico \\ ${ }^{2}$ Centre for Arid Zone Studies, University of Wales-Bangor, UK \\ ${ }^{3}$ Centro de Investigación y Tecnología Agroalimentaria de Aragón, \\ Lab. Asociado de Agronomía y Medio Ambiente (DGA-CSIC), Spain \\ ${ }^{4}$ Dept. Genética y Producción Vegetal (EEAD), \\ Lab. Asociado de Agronomía y Medio Ambiente (DGA-CSIC), Spain
}

\begin{abstract}
An assessment of water management in the Flumen District, Central Valley of the Ebro River Basin in Spain, using the remote sensing technique Surface Energy Balance Algorithm for Land (SEBAL) was performed. This assessment was based on the estimation of the actual ET $\left(\mathrm{ET}_{\mathrm{a}}\right)$ to compute net water volumes $(\mathrm{Vn})$. This work extended the analysis by also computing net irrigation volumes (Vi) by introducing a water application efficiency as a function of morphopedologic units $\left(\mathrm{Ea}_{\mathrm{m}}\right)$. Two approaches were adopted for SEBAL Vi: a) the crop water demands including months outside the crop season (SEBAL_F1) and $b$ ) the crop water demands of the six main crops only in the growing season (SEBAL_F2). The comparison analyses for SEBAL_F1 and SEBAL_F2 Vi show a very good agreement with a bias of $0.09 \mathrm{hm}^{3}$ and $0.56 \mathrm{hm}^{3}$, respectively. As a result of an accurate estimation of $\mathrm{Vi}$, the water use efficiency (Ea) for the whole Flumen District was determined to be from $80 \%$ to $90 \%$. These are actual figures, thus it is possible to review the current crop and water management, identifying the possible causes for low irrigation efficiency on some plots.

Keywords: crop water requirements, remote sensing, evapotranspiration, SEBAL, IRRIVOL, water resources management, Ebro Basin, Flumen District.
\end{abstract}




\section{Introduction}

For several hydrological and agricultural issues such as water resources management, irrigation scheduling, crop water requirements and others, to know how they are affected by the climatic and agronomic variations (soil and plant conditions) is basic. In order to cope with these variations it has been demonstrated that a confident estimation of evapotranspiration (ET) is essential, not only because it provides information that can be applied directly in the water budget, but also because ET has a high sensitivity which can be used to define some biophysical parameters [1]. Direct and indirect ET methods have been developed and give a good accuracy, however, some authors such as Schultz and Engman [2] have demonstrated that studies based on conventional field data collection are often limited because they cover only the area close to the weather station. Although this ET estimation is adequate for local studies, in large irrigated areas it is important to have reliable spatial and temporal ET values to determine the actual crop water demands and the water need over time. It is important to consider spatially distributed data covering any time period throughout the system. As no conventional method can be regarded as suitable to cover both spatial and temporal scale [3] and because the constant lack of data [4], an important alternative has been the introduction of remotely sensed data. This data can provide information about a specific crop and land condition covering both spatial and time variations. It has been demonstrated [2] that the combination of remotely sensed and ground-meteorological data can create more realistic and physically based models to analyse heterogeneous evaporative surfaces. Reliable $\mathrm{ET}_{\mathrm{a}}$ values produce accurate estimations of the real crop water requirements $\left(\mathrm{WR}_{\mathrm{n}}\right)$ and net crop water volumes $(\mathrm{Vn})$ for the irrigated districts.

In a first attempt [5], the Surface Energy Balance Algorithm for Land (SEBAL) [6] was applied to provide reliable $\mathrm{ET}_{\mathrm{a}}$ values for large areas. These values were used as input data in water management models such as the IRRIVOL methodology used in the Flumen district at the Central Ebro Valley (CEV), Spain [7]. A general problem in the Ebro Basin is the low water efficiency associated with the irrigation districts [8]. The direct benefits of accurate $\mathrm{Vn}$ values are the improvement of the water use. The conclusions of this study indicated that despite some variations observed between SEBAL and IRRIVOL, which uses the Blaney and Criddle equation to compute crop ET $\left(\mathrm{ET}_{\mathrm{c}}\right)$ [9], the agreement was good. The variations observed were mainly associated to climatic factors (haze and bochorno wind) present during the image capture. Once these variations were detected and removed from the analysis, the agreement obtained between both methods improved significantly. This confirmed that the SEBAL method provides $\mathrm{ET}_{\mathrm{a}}$ data that represents the actual spatial field conditions. However, for $\mathrm{WR}_{\mathrm{n}}$ and $\mathrm{Vn}$, the agreement between SEBAL and IRRIVOL was fair. The variations between the two methods could be ascribed to an arrange of causes including over-irrigation, use of additional water for land preparation, or atypical crop cultivation resulting in the actual crop development that differs from the theoretical one used by traditional methods. Also, an important difference was observed in the water requirements 
for constant flooded crops such as rice. The satellite data in this case could not determine the actual condition of the crop and the ground because the water layer. However, similar differences between the theoretical and practical rice $\mathrm{WR}_{\mathrm{n}}$ have been obtained using conventional methods making it necessary to consider an extra water requirement.

In this paper, the water demands analysis of the Flumen District has been extended to compute net irrigation volumes (Vi) considering the field and climatic factors identified previously and applying a water efficiency per morphopedologic units $\left(\mathrm{Ea}_{\mathrm{m}}\right)$. This will provide a real water efficiency (Ea) for the whole District and determine the actual crop water requirements and its impact on the availability of the water resources.

\section{Field sites}

The Ebro Basin is the most extensive hydrographical basin of Spain with an area of $85,399 \mathrm{~km}^{2}$ (almost $17.3 \%$ of the total country area) of which the Aragon Community occupies the Central Ebro Basin (CEB). In the Depression or Valley (CEV) at the CEB, which corresponds to a flat topography, the Riegos del Alto Aragon (RAA, Irrigation lands at the Aragon's Northern Area) system is located. The RAA is one of the most ambitious extensive irrigated districts in the Basin with an irrigated area of $1,685 \mathrm{~km}^{2}(71.4 \%$ of the total irrigated land in Aragon). The RAA is integrated by the subsystems: Cinca, Monegros, Flumen and Violada, each one is named according to the main canal that irrigates it [10,11], fig. 1 .

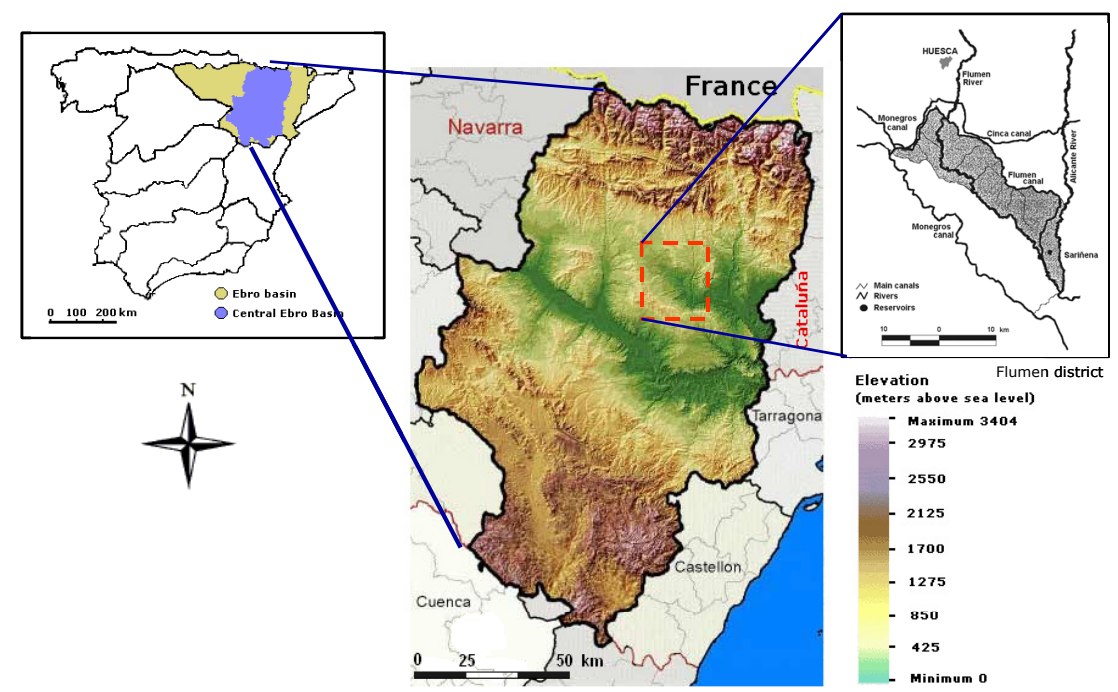

Figure 1: Central Ebro basin covering the Aragon Autonomous Community and the location of the Flumen District. 
The Flumen District covers an area of 33,729 ha $(20 \%$ of the RAA irrigated land) [10], it includes a main irrigation system (50 years old) and some enclaves (territories included within a bigger territory but with different geographic characteristics), and old irrigated plains (i.e. huertas, older than six centuries) along the riverbanks [7].

According to Bielsa et al. (1998), the physical availability of water in the $\mathrm{CEV}$ can be divided into the left and right banks, having the Ebro River as common collector. Thus, the canal system is very important since it provides the water for irrigation. Almost all rivers in the RAA system have an irregular flow and present salinity problems [10]. However, the water availability depends strongly of the climatic variations in the zone. Martínez-Cob and Tejero-Juste [12] reported for the CEV mean annual variations for precipitation from 354 to $475 \mathrm{~mm}$, for air temperature from 13.1 to $14.5^{\circ} \mathrm{C}$ and for air relative humidity from 65 to $76 \%$. Precipitation presents two maxims in spring and autumn, and two minimums in summer and winter. Wind speed for the Flumen is moderate (from $1.0-2.5 \mathrm{~m} \cdot \mathrm{s}^{-1}$ ), although the topography reinforces the influence of continental winds. In extreme conditions, a northwest winter wind called cierzo is present, whereas in summer there is a southeast dry and hot wind called bochorno. Both type of winds have a drying action, which imparts a high aridity to the zone throughout the year [10]. Although salinity of some soils is a constraint for agriculture, irrigation makes possible to grow a variety of crops. The main crops grown are: winter cereals (barley and wheat), maize, alfalfa, forage, rice, and sunflower covering an area around $66 \%$ of the District. They are responsible of most water consumption in the District [13].

\section{Data and methods}

This section provides a brief description of the available data to assess the applicability of remote sensing techniques in the computation of accurate $\mathrm{Vi}$ values. The methodology includes the estimation of $\mathrm{ET}_{\mathrm{a}}, \mathrm{WR}_{\mathrm{n}}$ and $\mathrm{Vn}$ these steps are mentioned briefly since they were reported in a previous paper [5].

\subsection{Data sources}

The meteorological data for the Flumen District were collected for the four-year study period (1997 to 2000) from two main sources: 1) Sariñena and Monflorite National Automatic Weather Stations Network (EMAs) that record 10-minute intervals for each variable measured (precipitation, air temperature, relative humidity, wind speed and wind direction and atmospheric pressure); and 2) Basic Weather Stations (BWS) that record daily precipitation and temperature and some stations also recorded sunshine hours.

The phenological information collected was sown and harvested dates, and vegetation characteristics such as height. Also, records of water delivered by the Ebro Hydrographical Confederation (CHE) were available in a continuous daily basis, thus records of the monthly and annual water requirements $\left(\mathrm{V}_{\mathrm{nCHE}}\right)$ were achieved. The CHE supplies the water requested for the farmers, who estimate 
the water demands based on the crop sown and the area occupied using empirical methods, experience or both. The CHE checked the amount of water requested with the land area registered and the crop declared to be sown, however, the water application is determined by the farmer.

Finally, fifteen Landsat images (TM and ETM+ sensors) were used for the four-year study period. Images were acquired for the maximum crop-growth stage periods, thus summer images were chosen. Winter images have not been included, because winter crops are in their initial stage (more bare soil) or they have not been sown yet. The images were atmospheric, geometric and radiometrically corrected. Also, an enhancement was performed and problems associated to haze occurrence were identified. As result, two images were eliminated from the analysis.

\subsection{Methods}

For a number of years, $\mathrm{ET}_{\mathrm{c}}$ in the Flumen District has been calculated using the Blaney-Criddle (BC) equation with data from the Sariñena BWS, local experimental crop coefficients $(\mathrm{Kc})$, and corrected by a local coefficient of 0.88 . These $B C-E T_{c}$ values have been utilised in the IRRIVOL methodology that follow the FAO guidelines to compute $\mathrm{WR}_{\mathrm{n}}$ and $\mathrm{Vn}$ [9]. The IRRIVOL methodology utilises remotely sensed data to derive an annual land coverclassification map for the six main crops. This map is combined with meteorological data to provide $\mathrm{WR}_{\mathrm{n}}$ and $\mathrm{Vn}$ maps using Geographical Information System (GIS) techniques [7]. The estimation of water requirements includes zones with and without water metering points or plots with potential reuse (runoff or seepage) [13].

The advantage using remotely sensed data was increased by the use of remote sensing algorithms such the SEBAL technique. This involves the determination of the land surface physical parameters from spectral reflectance and radiance and the introduction of meteorological data such as air temperature, humidity, and wind speed at a reference height. The SEBAL technique uses these variables to estimate the energy flux parameters (sensible, soil and latent) and obtains ET $_{\mathrm{a}}$ as the residual form of the energy balance equation [14]. The SEBAL ET $\mathrm{a}_{\mathrm{a}}$ values correspond to the instant of satellite overpass, thus a temporal interpolation must be made to determine daily values. Moreover, as the CHE water invoices are available in a monthly basis, the crop water demands need to be compared on this timescale. Thus, the SEBAL daily $\mathrm{ET}_{\mathrm{a}}$ values are extrapolated to monthly values using scaling factors developed from the FAO-56 Penman-Monteith equation [15]. Monthly SEBAL ET $\mathrm{a}_{\mathrm{a}}$ values were used to compute SEBAL $\mathrm{WR}_{\mathrm{n}}$ subtracting the effective precipitation (Pe) from SEBAL $E_{\mathrm{a}}$ according to Cuenca [16]. Pe was assigned as fixed value to each pixel using Thiessen polygons.

IRRIVOL computes $\mathrm{WR}_{\mathrm{n}}$ on a monthly basis subtracting the value of $\mathrm{Pe}$ from the $\mathrm{BC}_{-} \mathrm{ET}_{\mathrm{c}}$. Then $\mathrm{WR}_{\mathrm{nIRRIVOL}}$ values are assigned according to the land

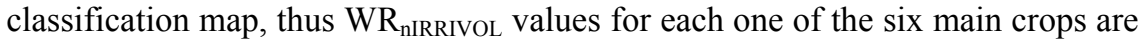
obtained. SEBAL $\mathrm{WR}_{\mathrm{n}}$ are compared with IRRIVOL $\mathrm{WR}_{\mathrm{n}}$ obtained from previous researches [13]. 
As the land cover classification maps were available for each year under study, the SEBAL and IRRIVOL $\mathrm{WR}_{n}$ values were multiplied for the hectarage of the six main crops to compute Vn per crop, and these are then summed up to obtain the total monthly Vn for both IRRIVOL and SEBAL. For SEBAL Vn predictions, two approaches were adopted. The first considered the crop water demands including months out of crop season (SEBAL_F1) and compared the $\mathrm{Vn}$ estimate with the water delivery invoices by $\mathrm{CHE}$, that is the water supplied for irrigation. The second considered the crop water demands for only the six main crops growing period (SEBAL_F2) and the Vn values obtained were compared with those obtained by IRRIVTOL [13].

The irrigation water volumes (Vi) were calculated as indicates eq. 1.

$$
\mathrm{Vi}=\mathrm{V}_{\mathrm{n}} \times \mathrm{Ea}_{\mathrm{m}}^{-1}, \mathrm{hm}^{3}
$$

where $\mathrm{Ea}_{\mathrm{m}}$ is the soil water efficiency, which was obtained experimentally for each of the morphopedological units in the Flumen District [17], table 1 [18]. Vi values for both SEBAL and IRRIVOL were computed for each type of crop and for each type of structure. In order to check if these calculated values correspond to the actual water demands, a final comparison was made using the water delivery $\mathrm{CHE}$ records $\left(\mathrm{V}_{\mathrm{CHE}}\right)$.

Table 1: $\quad$ Surface water application efficiency for land evaluation units in the Flumen District.

\begin{tabular}{|c|c|c|}
\hline Morphologic type & Area, (ha) & Efficiency, $\mathrm{Ea}_{\mathrm{m}}$ \\
\hline Platforms & 7558 & 0.4 \\
\hline Slopes & 17263 & 0.6 \\
\hline Terraces & 2905 & 0.8 \\
\hline Bottoms & 4517 & 0.8 \\
\hline
\end{tabular}

\section{Results}

The $\mathrm{ET}_{\mathrm{a}}$ validation process carried out to test the reliability of the SEBAL technique at regional (Flumen District) scale confirmed that SEBAL produces reliable representations of the ground and crop conditions except for crops under constant flooded fields such as rice. These differences occur because the satellite sensed the rice fields as shallow water bodies. Thus, the standing water background affects the spectral reflectance of rice, the sensitivity of spectral vegetation indices and the surface temperature (Ts), which is lower than would be observed for this crop under a different irrigation system [19,20].

\subsection{Crop water requirements, WRn}

As SEBAL can detect variations associated to irrigation practices, rainfall events and climatic variations on the particular instant of satellite overpass, the estimation of $\mathrm{WR}_{n}$ has a high level of confidence. SEBAL $\mathrm{WR}_{n}$ values were 
lower than $\mathrm{WR}_{\text {nIRRIVOL }}$ since they involve the actual conditions on the field including changes in the crop development, fig. 2.

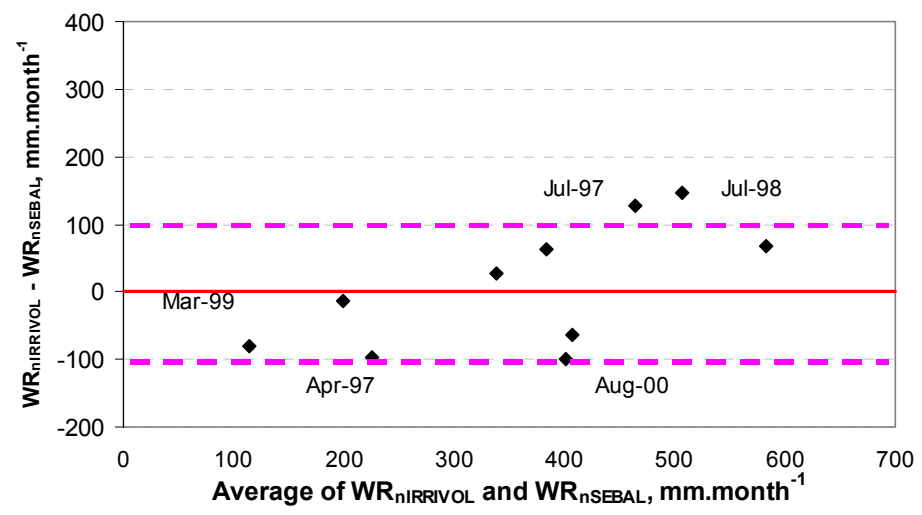

Figure 2: Differences between $\mathrm{WR}_{\mathrm{nSEBAL}}$ and $\mathrm{WR}_{\mathrm{nIRRIVOL}}$ without rice $\mathrm{WR}_{\mathrm{n}}$. Dotted lines are the upper and lower limits of the standard deviation of the differences (sdiff).

The most significant $\mathrm{WR}_{\mathrm{n}}$ differences were observed for sparse canopies such as sunflower $(\mathrm{SF})$, maize $(\mathrm{M})$ and rice $(\mathrm{R})$ and during the summer season. The $\mathrm{WR}_{n}$ variations for rice were considerable because the irrigation practice, which was a limitation for the SEBAL procedure. Rice IRRIVOL $\mathrm{WR}_{\mathrm{n}}$ uses the Tolosa adjustment [21] that adds an empirical factor of $15,000 \mathrm{~m}^{3} \cdot \mathrm{ha}^{-1}$ to the theoretical $\mathrm{WR}_{\mathrm{n}}$ values in order to cope the crop water demands. However, this factor was not considered appropriate for SEBAL, because the algorithm could reflect accurately the crop and ground conditions.

Casterad [22] explained the $\mathrm{WR}_{\mathrm{n}}$ under-estimations obtained using IRRIVOL as result of an inappropriate estimation of the Pe. This is because rainfall in summer is short and heavy followed by strong wind and high temperatures that dry the foliage almost immediately [22]. However, this is an aspect that merits further work.

\subsection{Crop water volumes, Vn}

SEBAL_F1 was expected to be close to the CHE invoices, which recorded the total monthly water supplied to the whole district. SEBAL_F2 should be similar to the $\mathrm{Vn}_{\text {IRRIVOL }}$ values, since they are also restricted to the crop period established, according to the practice in the Flumen District. As a result, SEBAL_F2 and IRRIVOL Vn values should be lower than the CHE records, because the six main crops are responsible for almost $90 \%$ of the overall water requirements. However, significant $V_{n}$ differences were obtained between IRRIVOL and SEBAL, and these were mainly related to the SEBAL problems for rice fields, fig. 3 . 


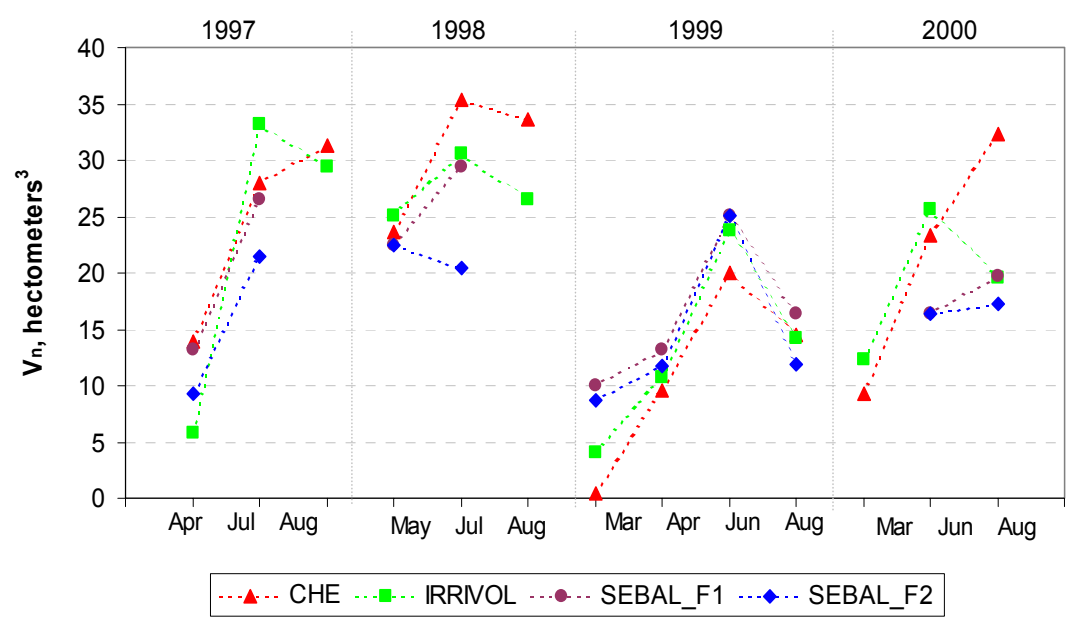

Figure 3: $\quad$ Net water volumes $\left(\mathrm{Vn}_{\mathrm{n}}\right), \mathrm{hm}^{3}$ for CHE, IRRIVOL and SEBAL.

To allow the comparison of total volumes with CHE data, and knowing that IRRIVOL already includes for rice the Tolosa adjustment factor $\left(15,000 \mathrm{hm}^{3}\right)$, the rice- $\mathrm{V}_{\text {nIRRIVOL }}$ were used instead of the rice- $\mathrm{V}_{\text {nSEBAL }}$. Thus, total SEBAL_F1 and SEBAL_F2 Vn were adjusted as indicated in eqs. 2 and 3:

$$
\begin{aligned}
& \mathrm{V}_{\text {nSEBAL }} \mathrm{Fl}_{(\mathrm{r}-\mathrm{adj})}=\left\lfloor\text { total } \mathrm{V}_{\mathrm{nSEBAL} \_} \mathrm{F}_{1}-\mathrm{riceV}_{\mathrm{nSEBAL}_{-} \mathrm{Fl}}\right\rfloor+\text { riceV }_{\text {nIRRIVOL }} \\
& \left.\mathrm{V}_{\text {nSEBAL_F2 }} \text { r }- \text { adj }\right)=\left\lfloor\text { total } \mathrm{V}_{\text {nSEBAL_F2 }}-\operatorname{riceV}_{\text {nSEBAL_F2 }}\right\rfloor+\operatorname{riceV}_{\text {nIRRIVOL }}
\end{aligned}
$$

Fig. 4 shows a good match between $\mathrm{V}_{\mathrm{nCHE}}$ and $\mathrm{V}_{\mathrm{nSEBAL}} \mathrm{F}_{(\mathrm{r}-\mathrm{adj})}$ and $\mathrm{V}_{\text {nIRRIVOL }}$

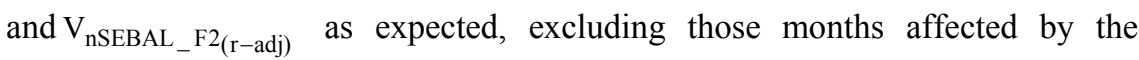
bochorno wind and haze problems and Mar-99 due to the water shortage in the dams at the Pyrenees, which provide river flows and the irrigation water to the Districts.

The final agreement between SEBAL_F1(r-adj) and CHE was good with a bias of $-1.45 \mathrm{hectm}^{3}$ and a $\mathrm{s}_{\text {diff }}$ of $\pm 4.95 \mathrm{hm}^{3}$. The comparison between IRRIVOL and CHE indicates that the crop water requirements are higher than the water supplied by the CHE. As IRRIVOL only considers the water demands for the six main crops, this result was foreseen. Although, the agreement between IRRIVOL and SEBAL_F2(r-adj) was expected good it was moderate, quite similar to the one obtained between CHE and IRRIVOL, giving a bias of 1.49 and a sdiff of $\pm 5.74 \mathrm{hm}^{3}$.

The reliability of the $V n_{\text {SEBAL }}$ values obtained allows the introduction of irrigation performance indicators, which permit to evaluate the performance of an irrigated district based on their sensitivity to the irrigation management [23]. In this work, the ratio between RECORDED/COMPUTED Vn [13] or the field 
application ratio $(\mathrm{Ea}=\mathrm{COMPUTED} / \mathrm{RECORDED} \mathrm{Vn})$ were used. These rations together with a major farmers' participation help to monitor, identify and quantify some problems in order to reduce the low water efficiencies. This low efficiency could be related to differences between the estimated and reported cropped area, poor crop husbandry (e.g. sunflower which is often grown only to receive the EU subsidy), not considering the water requirements for tillage, or non-accurate water request for supply by the farmer.

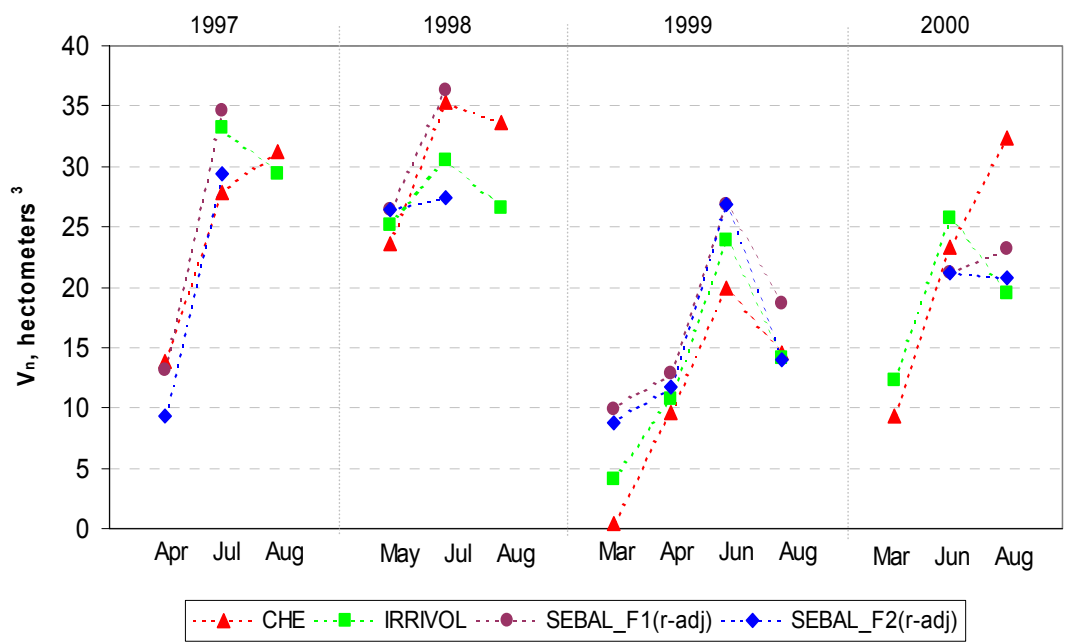

Figure 4: CHE, IRRIVOL and SEBAL net water volumes $(\mathrm{Vn}), \mathrm{hm}^{3}$ adjusted.

\subsection{Net irrigation volumes, $\mathrm{Vi}$}

$\mathrm{Vi}_{\text {IRRIVOL }}$ values were taken from previous research in the area for each of the years under study [24]. Rice- $\mathrm{Vi}_{\text {IRRIVOL }}$ values were considered the same for rice$\mathrm{V}_{\text {nIRRIVOL }}$ because of the irrigation method. For SEBAL again the two approaches SEBAL_F1 and SEBAL_F2 were considered as well for SEBAL $V_{\mathrm{n}}$. In a similar way to $\mathrm{V}_{\mathrm{n}}$, to evaluate properly the differences observed for the SEBAL estimations and knowing that IRRIVOL already considers for rice the Tolosa adjustment factor, the rice- $\mathrm{Vi}_{\text {IRRIVOL }}$ were used instead of the rice- $\mathrm{Vi}_{\text {SEBAL }}$. Thus, total SEBAL_F1 and SEBAL_F2 Vi are redefined as indicated in eqs. 4 and 5:

$$
\begin{aligned}
& \mathrm{Vi}_{\text {SEBAL }} \mathrm{Fl}_{(\mathrm{r}-\mathrm{adj})}=\left\lfloor\text { total } \mathrm{Vi}_{\mathrm{SEBAL}_{-} \mathrm{F} 1}-\mathrm{riceVi}_{\mathrm{SEBAL}_{-} \mathrm{F} 1}\right\rfloor+\text { riceVi }_{\text {IRRIVOL }} \\
& \mathrm{Vi}_{\left.\mathrm{SEBAL}_{-} \mathrm{F}_{(\mathrm{r}-\text { adj }}\right)}=\left\lfloor\text { total } \mathrm{Vi}_{\mathrm{SEBAL}_{-} \mathrm{F}_{2}}-\mathrm{riceVi}_{\mathrm{SEBAL}_{-} \mathrm{F} 2}\right\rfloor+\text { riceVi } \mathrm{I}_{\text {IRRIVOL }}
\end{aligned}
$$

Fig. 5 shows the $\mathrm{Vi}$ differences obtained for CHE\&SEBAL_F1 $1_{(\mathrm{r}-\mathrm{adj})}$ and IRRIVOL\&SEBAL_F2 $2_{(\mathrm{r}-\mathrm{adj})}$ plotting the differences against their averages. 


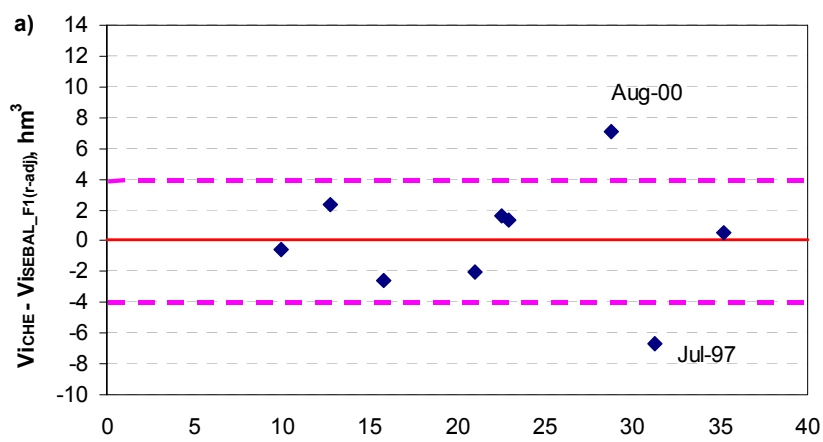

Average of $\mathrm{Vi}_{\text {CHE }}$ and $\mathrm{Vi}_{\text {SEBAL_F1 }(r-a d j)}, \mathrm{hm}^{3}$

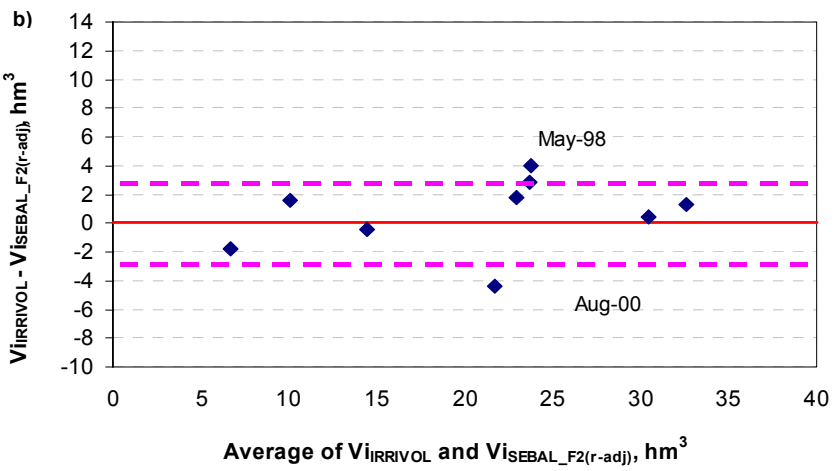

Figure 5: $\quad$ Monthly $\mathrm{Vi}, \mathrm{hm}^{3}$, differences plotted against their average between (a) CHE\&SEBAL_F1(r-adj) and (b) IRRIVOL\&SEBAL_F2 (r-adj).

The difference range for CHE\&SEBAL_F1(r-adj) and IRRIVOL\&SEBAL_F2 (r-adj) remains almost constant as the average increases. The agreement between CHE and SEBAL_F1(r-adj) was good with a bias of $0.09 \mathrm{hm}^{3}$ and a $\mathrm{s}_{\text {diff }}$ of $\pm 3.82 \mathrm{hm}^{3}$; the months with higher differences were Jul97 and Aug-00. Also, the agreement between $\mathrm{Vi}_{\text {IRRIVOL }}$ and $\left.\mathrm{Vi}_{\text {SEBAL }_{-}}{ }_{2} 2_{(\mathrm{r}-\mathrm{adj}}\right)$ was good with a bias of $0.56 \mathrm{hm}^{3}$ and a $s_{\text {diff }}$ of $\pm 2.53 \mathrm{hm}^{3}$. The main advantage of accurate Vi values is that Ea can be calculated with high accuracy for the whole system. In this case, Ea was around $90 \%$ for each year under study.

Additionally, the SEBAL Vi map not only permits the analysis for the whole district, but also, very significantly, the analysis at field scale can be achieved with high precision, fig 6.

For the first time this allows those plots with low water efficiency to be pinpointed, allowing specific, targeted actions to be taken to improve crop management and, in consequence, guarantee better water and land use. 


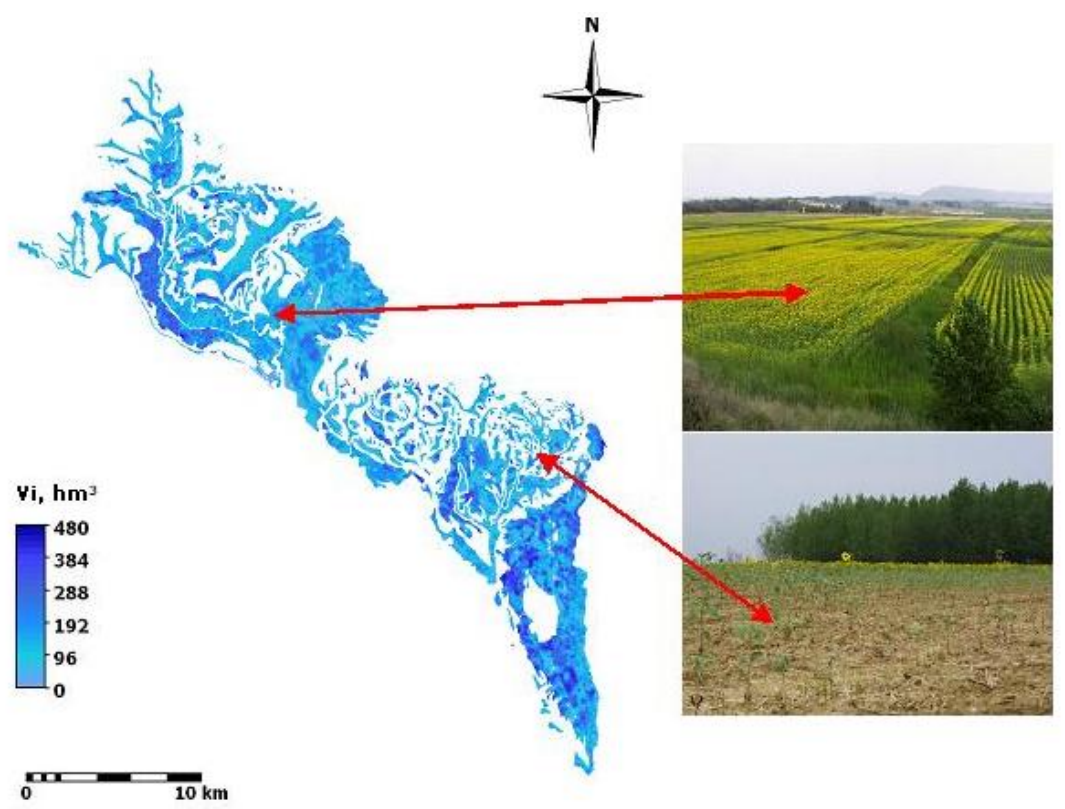

Figure 6: Irrigation requirements, Vi $\left[10^{6} \mathrm{~m}^{3}\right]$, in the Flumen District. Image date Aug $14^{\text {th }} 1999$. Zero values are covers non-classified.

\section{Conclusions}

The differences observed between SEBAL- $1_{(\mathrm{r}-\mathrm{adj})}$ and CHE highlight some problems of the CHE in achieving an effective timing and allocation of water requirements and quite frequently CHE tends to cause over-delivery of water.

Results obtained give confidence in the use of SEBAL to compute the irrigation volumes, although for rice-water requirements further studies are required. This confirms that the SEBAL procedure is one of a number of techniques that identify crop-water-soil conditions using satellite based remote sensing. This facilitates crop, land and water management offering a wide range of alternatives to maximise yield with less water use. Spatial coverage permits the detection of spatial inconsistencies related to the crop conditions, water application, soil types, micro-relief, etc. On a regional scale, the computation of more accurate water balances will allow the allocation or re-allocation of the water resources. Also, the analysis of alternative crops could be based on its water and land requirements and not only on its economic value. On a local scale, the identification of problems associated with the crop development can be achieved, thus improving the crop management, which can be monitored using $\mathrm{ET}_{\mathrm{a}}, \mathrm{V}_{\mathrm{n}}, \mathrm{Vi}$, or the crop yield. 


\section{Acknowledgements}

The authors would like to thank Dr. Allen and Dr. Bastiaanssen for their support during the study. The authors gratefully acknowledge the financial support of DGAPA-UNAM and CONACyT, Mexico. This paper was presented at the River Basin Management 2005 conference in Bologna, Italy.

\section{References}

[1] Lakshmi V. \& Susskind J., Utilization of satellite data in land surface hydrology: sensitivity and assimilation. Hydrology Process, 15, pp. 877892, 2001.

[2] Schultz G. A. \& Engman E.T., Remote Sensing in Hydrology and Water Management. Springer-Verlag: Heidelberg, 2000.

[3] Kite G. and Droogers P., Comparing estimates of actual evapotranspiration from satellites, hydrological models, and field data: A case study from Western Turkey. Research Report No. 42, International Water Management Institute, pp. 32, Colombo, Sri Lanka, 2000.

[4] GWP TAC, Integrated Water Resources Management. Technical Advisor Committee of the Global Water Partnership, Background No.4, pp.71, Stockholm, Denmark, 2000.

[5] Ramos J.G., Cratchley R., Kay J.A., Casterad M.A., Martínez-Cob A. \& Herrero J., Comparison of the SEBAL and the traditional FAO procedure for water volume estimation in an irrigation district. New Strategies for European Remote Sensing, ed. Marinko Oluic, Millpress: Rotterdam, pp. 515-522, 2005.

[6] Bastiaanssen W.G.M., Menenti M., Feddes R.A.\& Holtslag A.A.M., A remote Sensing Surface Energy Balance Algorithm for Land (SEBAL), Part 1: Formulation, Journal of Hydrology, 212-213, pp. 198-212, 1998.

[7] Casterad M. A. \& Herrero J., Irrivol: A method to estimate the yearly and monthly water applied in an irrigation district, Water Resources Research, 34, pp. 3045-3049, 1998.

[8] Dechmi F., Playán E., Faci J.M., Tejero M. \& Bercero A., Agricultural analysis of an irrigation district in north eastern Spain II. Irrigation evaluation, simulation and scheduling, Water Management, 61, pp. 93$109,2003$.

[9] Doorenbos J. \& Pruitt W.O., Guidelines for Predicting Crop Water Requirements. Paper. No. 24, Irrigation and Drainage. UN Food and Agriculture Organisation. Rome, 1977.

[10] Confederación Hidrográfica del Ebro (CHE), www.oph.chebro.es.

[11] Los regadíos en Aragón. Gobierno de Aragón; Oficina del Regante. On line. http://web.eead.csic.es/oficinaregante/mapas/mapas28.htm.

[12] Martínez-Cob A. \& Tejero-Juste M. A., wind-based qualitative calibration of the Hargreaves ETo estimation equation in semiarid regions, Agricultural Water Management, 64, pp. 251-264, 2004. 
[13] Herrero, J. \& Casterad, M.A., Using satellite and other data to estimate the annual water demand of an irrigation district. Environmental Monitoring and Assessment, 55, pp. 305-317, 1999.

[14] Bastiaanssen W.G.M. and Bandara, Evaporative Depletion Assessments for Irrigated Watersheds in Sri Lanka. Irrigation Science, 21, 1-15, 2001.

[15] Allen R.G., Pereira L.S., Raes D. \& Smith M., Crop Evapotranspiration. Guidelines for Computing Crop Water Requirements, Paper No. 56, Irrigation and Drainage. UN Food and Agriculture Organisation. Rome, 1998.

[16] Cuenca R.H., Irrigation System Design: An Engineering Approach, Prentice Hall: New Yersey, 1989.

[17] Nogués J., Evaluación de las tierras mediante la aplicación del método FAO 1976 y su integración en un sistema de información territotial, en las 26000 ha (sectores IV al XI), regadas po rel canal de Flumen (Huesca). Proyecto de Investigación de Final de Carrera, Departamento de Medio Ambiente y Ciencia del Suelo, Escuela Técnica Superior de Ingeniería Agraria: Universitad de Lleida, pp.160 plus annex and maps, Spain, 1994.

[18] Martín-Ordóñez T., Casterad M. A. \& Herrero J. Three years of mapping irrigation water in the Flumen irrigation district, Spain, ed. J.L. Casanova, Remote Sensing in the 21st Century: Economic and Environmental Applications, Balkema: Rotterdam pp. 191-194, 2000.

[19] Casterad M.A. Personal communication, 19 May 2002. Leader of the Remote Sensing Group, Centro de Investigación y Tecnología Agroalimentaria de Aragón, Lab. Asociado de Agronomía y Medio Ambiente (DGA-CSIC), Zaragoza, Spain.

[20] Xiao X., He L., Salas W., Li C., Moore III B., Zhao R., Frolking S. \& Boles S., Quantitative relationships between field-measured leaf area index and vegetation index derived from vegetation images for paddy rice. Int. J. Remote Sensing, 23(18), pp. 3595-3604, 2002.

[21] Tolosa M., El cultivo del arroz. Informaciones Técnicas, DGPA, pp.8. Diputación General de Aragón, Zaragoza, Spain, 1990.

[22] Casterad M. A., Teledetección y aforo de superficies de cultivos en pequenas demarcaciones para estimar el agua aplicada por poligonos de riego, $\mathrm{PhD}$ Dissertation, Departamento de Medio Ambiente y Ciencia del Suelo, Escuela Técnica Superior de Ingeniería Agraria: Universitad de Lleida, Spain, 1997.

[23] Bos M.G. Performance Assessment of Irrigation and Drainage. Lecture Notes for the International Course on Diagnosing Irrigation Practices with Satellite Remote Sensing. ITC\&ILRI, Apr 8-26, 2002, Enschede, The Netherlands, 2002.

[24] Santos, E. Delimitación de áreas propensas a salinización mediante mapas de riego y de suelos. Proyecto del Postgrado de Ingeniería Medio Ambiental, Centro Politécnico Superior: Universidad de Zaragoza, pp.81, 2003. 